\title{
'n Kwalitatiewe ondersoek na die invloed van aspekte van die klerewinkel en die verkoopsdame se voorkoms op die dameskler- everbruiker se besluitnemingsproses
}

\author{
HM de Klerk, AK Velleman, E Malherbe*
}

\begin{abstract}
The literature and research on consumer behaviour indicate that consumers are not only influenced by individual variables when they make consumer choices, but also by environmental influences and the purchase situation as such. The retail environment is but one aspect of life where one is bombarded with thousands of stimuli. With the underlying viewpoints of symbolic interactionism and a cognitive perspective in mind, one could argue that consumers may use and interpret these stimuli as symbols of some aspects of the buying situation and environment. The central question for this study was the extent to which the exterior of the clothing store and the appearance of the salesladies influence the adult female consumer's decision-making process.
\end{abstract}

A qualitative research style was chosen, with unstructured interviewing, participative observation, analysis of photos and respondents' stories as data-collection techniques. The study supports the viewpoints of the chosen perspectives regarding peoples' use of environmental objects as symbols and with regard to the important role other people and one's self play in one's expectations and social cognition.

The exterior of the clothing store and the appearance of the saleslady are two major stimuli that are interpreted by adult female consumers when they visit a clothing store. When an adult female consumer thinks that the exterior image of a clothing store and the appearance of the saleslady fit her self-image, she is likely to enter the store, take advice from the saleslady and return for further purchases.

\section{- Prof HM de Klerk *}

Departement Huishoudkunde, Universiteit van Pretoria

\section{- Me AK Velleman *}

Gebaseer op Honeursprojek

- Me E Malherbe *

Gebaseer op Magisterprojek

\section{AGTERGROND}

Op feitlik elke terrein van die lewe is daar verskeie stimuli wat gedrag beïnvloed. Hierdie stimuli behels volgens Baron en Byrne (1987:76) insette wat 'n persoon uit die omgewing ontvang en wat waarskynlik sy of haar gedrag gaan beïnvloed. 'n Mens ontvang veral stimuli uit die handelswêreld, en die klerewinkel is geen uitsondering nie (Drake et al, 1992:17).

Met die onderliggende aannames van die simboliese interaksionisme en 'n kognitiewe perspektief in gedagte sou 'n mens kon sê dat verbruikers hierdie stimuli as simbool kan interpreteer ten einde betekenis daaraan te heg. Gevolglik kan dit hulle persepsies, houdings en uiteindelike gedrag met betrekking tot die winkel beïnvloed. Sproles (1980:195) beklemtoon dat reeds die winkelaansig só beplan kan word dat dit sekere verlangde reaksies by verbruikers kan uitlok, en O'Neal en Lapitsky (1991) wys daarop dat die klere wat 'n persoon, byvoorbeeld die verkoopsdame dra uiteindelik weer ' $n$ invloed op ander, in dié geval op die verbruiker, kan hê.

Kommunikasie is 'n tweerigtingproses. Charon (1979:39) benadruk vanuit die simboliese interaksionisme dat sinvolle kommunikasie, met uiteindelike hamonie tussen die individu en ander, slegs kan plaasvind indien die stimuli uit die omgewing deur die bepaalde individu geïnterpreteer en verstaan word en hom of haar dus beïnvloed soos bedoel was toe die boodskap uitgestuur is. 'n Individu stap immers as aktiewe, denkende wese die situasie binne, met 'n bepaalde self wat in interaksie met ander ontwikkel het en beïnvloed word. Hierdie self sluit onder meer die individu se waardes, norme, idees, verwagtings en so meer in. Drake et al (1992:15-38) is van die min skrywers wat groot klem lê op die invloed van die klereverbruiker se verwagtings en bepaalde selfbeeld op die persepsies wat hy of sy tydens klere-aankope in die winkel vorm. Hierdie skrywers stel onomwonde dat, indien die verbruiker se persepsies van 'n bepaalde winkel, hetsy gevorm as gevolg van berigte in die massamedia of die winkelaansig, of vanweë ander invloede in die winkel, nie versoenbaar is met sy of haar bepaalde verwagtings en behoeftes nie, hy of sy waarskynlik nie die moeite sal doen om die winkel weer te besoek nie. Die skrywers pleit daarom vir meer kledingnavorsing vanuit ' $n$ verbruikersoogpunt ten einde ' $n$ beter beeld van die verbruiker se 
verwagtings en persepsies te kry.

Die volgende oorkoepelende vrae is gevolglik vir hierdie studiedoeleindes gevra:

- Watter invloed het die aansig van damesklerewinkels op die persepsies wat dames van die winkels vorm?

- Watter invloed het die verkoopsdame se voorkoms op die damesklereverbruiker se besluitnemingsproses?

Die vrae word aangespreek vanuit die perspektiewe van die simboliese interaksionisme en 'n kognitiewe benadering, met die kledingverbruikersteorie as agtergrond.

\section{DIE LITERATUUR}

Volgens Mouton en Marais (1990:146-147) is die keuse van 'n navorsingsperspektief van groot belang aangesien dit die navorser tot bepaalde teorië, voorveronderstellings en aannames verbind en ' $n$ bepaalde navorsingsmetodologie aan die navorser voorhou. 'n Aantal fokuspunte van die simboliese interaksionisme het as agtergrond vir dié studies gedien:

Die simboliese interaksionisme fokus eerstens op die interaksie tussen ' $n$ individu en ander individue en groepe, tussen die individu en sy omgewing asook interaksie binne die individu self (Charon, 1979:133150). Die damesklereverbruiker is in dié geval in interaksie met haar omgewing, naamlik die aansig van die damesklerewinkel, asook met ander individue, in dié geval die verkoopsdame. Dit mag moontlik ' $n$ invloed op haar persepsievorming hê. Sy is egter ook in interaksie met die self omdat sy met haarself in gesprek tree oor onder meer die persepsies wat sy vorm.

Die simboliese interaksionisme stel tweedens dat die individu ' $n$ aktiewe, denkende wese is wat onder meer ook beïnvloed word deur die perspektiewe, idees, gelowe, waardes, verwagtings en so meer wat hy of sy uit die verlede in die situasie indra (Charon, 1979:8896). In dié geval sal die damesklereverbruiker se verwagtings, idees, waardes en so meer dus in die winkelsituasie ingedra word en 'n invloed hê op die persepsies wat sy vorm. Hierdie verwagtings, idees, waardes en so meer is tydens interaksie met ander aangeleer en deel van die self gemaak (Van Rensburg \& De Klerk, 1989).

Derdens fokus die simboliese interaksionisme op die belangrike feit dat mense gedurig aspekte of objekte uit hul omgewings gebruik om betekenis te gee aan die sosiale interaksie waarby hulle betrokke is. Hierdie objekte kry betekenis en word gebruik om simboliese betekenis en verstaanbaarheid aan hul lewens te gee (Charon, 1979:39). In hierdie geval reageer die damesklereverbruiker dus op aspekte van die winkelaansig en die verkoopsdame se voorkoms wat sy dan as simbool gebruik om 'n bepaalde boodskap, byvoorbeeld dié van bekwaamheid, status of prestige te simboliseer.

In aansluiting by die simboliese interaksionisme is ' $n$ kognitiewe perspektief gerig op menslike denke, veral op die persepsies wat mense van ander, van hul omgewing en van hulself vorm. 'n Kognitiewe perspektief bied dus groter duidelikheid oor hoe betekenisse tydens interaksie gevorm word (Baron \& Byrne, 1987:36-65). Die volgende fokuspunte is op hierdie studies van toepassing:

Eerstens word daar, in aansluiting by die simboliese interaksionisme, benadruk dat mense rasionele, denkende wesens is wat probeer sin maak uit die wêreld waarin hulle woon. Kognitiewe prosesse word gebruik om eksterne stimuli vanuit die omgewing te verwerk en te interpreteer. Om egter ' $n$ komplekse realiteit te kan hanteer, ontwikkel mense dikwels kortpaaie sodat inligting vinnig verwerk kan word. In die aankoopsituasie word die damesklereverbruiker aan 'n verskeidenheid stimuli blootgestel wat die situasie kompleks kan maak. Die damesklereverbruiker poog dan om, onder meer deur die gebruik van simbole, die inligting te verwerk sodat sy 'n besluit oor die winkel en die verkoopsdame kan neem (Miller \& Schlitt, 1985:38).

'n Belangrike fokuspunt van 'n kognitiewe benadering is dat mense gewoonlik aktuele, tydelike oorsake vir ander se gedrag soek in ' $n$ poging om ander te verstaan en om sekere persepsies te kan vorm (Baron \& Byrne, 1987:39). Die damesklereverbruiker wil moontlik iets van die winkel of die verkoopsdame se bekwaamheid weet alvorens sy besluit of sy die winkel wil binnegaan of haar aan die opinie van die verkoopsdame gaan steur. Hiedie inligting word gewoonlik oorgedra deur nie-verbale leidrade, soos leidrade uit die winkel of in die verkoopsdame se voorkoms. Volgens Baron en Byrne (1987:39) probeer mense ook om die langtermynoorsake van ander se aksies te voorspel. Die proses waarvolgens mense poog om hierdie inligting te bekom, staan bekend as attribusie en het as kognitiewe kortpad 'n invloed op die persepsies wat mense van ander en van situasies vorm (Baron \& Byrne, 1987:47).

Vanuit die verbruikersgedragteorie stel Rousseau (1990:48) dat verbruikersbesluitneming deur 'n hele aantal veranderlikes beïnvloed kan word:

Invloede vanuit die individu self soos behoeftes, motiewe, persoonlikheid, persepsievorming, leervermoë en houdings

- Omgewingsinvloede, waaronder kultuur, sosiale konteks, verwysingsgroepe, die gesin, ekonomiese faktore en besigheids- en bemarkingstrategieë, en 
- Invloede in die aankoopsituasie, waar inligting uit die omgewing met persoonlike behoeftes, motiewe, persepsies, houdings en so meer geïntegreer word.

Die invloed wat hierdie veranderlikes in die aankoopsituasie op die individu kan hê, word in Figuur 1 voorgestel.

So 'n raamwerk wat op die verbruikersgedragteorie berus is versoenbaar met die uitgangspunte van die simboliese interaksionisme en 'n kognitiewe perspektief. Hierdie uitgangspunte stel dit duidelik dat die individu ' $n$ aktiewe, denkende wese is, wat nie bloot op impulse reageer nie maar met bepaalde behoeftes, motiewe, houdings, ' $n$ selfbeeld en so meer, 'n situasie binnestap en dan deur die interaksie met ander en met die omgewing beïnvloed word. Hierdie invloede kan weer die persoon se uiteindelike gedrag beïnvloed.

Daarmee saam moet in gedagte gehou word dat die verbruikersbesluitnemingsproses ingewikkeld is en dat dit uit verskillende fases bestaan waarvan die aankoopfase in die winkel maar een is. Rousseau (1990:46) wys daarop dat hierdie proses nog ingewikkelder raak wanneer dit kom by produkte wat met die verbruiker se selfbeeld geassosieer word, ondermeer sy of haar kleding. Die wyses waarop dié ingewikkelde besluitnemingsproses vereenvoudig kan word, sluit sekere kognitiewe strukture en kortpaaie in, onder andere die interpretasie van aspekte van die omgewing as simbole, die gebruik van persoons- en omgewingskemata, en die toepassing van attribusie en stereotipering. Dié siening is versoenbaar met die basiese uitgangspunte van die simboliese interaksionisme en van ' $n$ kognitiewe perspektief (Charon, 1979:22-23; Baron \& Byrne, 1987:37-75).

Dit is aan die hand van die kledingteorie en navorsing duidelik dat die kledingbesluitnemingsproses nie noodwendig deur dieselfde faktore beïnvloed word as byvoorbeeld besluitneming oor ander toerusting en apparaat nie. Eckman et al (1990) het byvoorbeeld gevind dat die damesklereverbruiker se finale besluit in die winkel definitief beïnvloed word deur haar persepsies van die pas, algemene styl en voorkoms van die kledingstuk, terwyl Drake et al (1992:20) daarop wys dat die finale beeld wat die klereverbruiker van haarself het, beïnvloed word deur onder meer haar ideale selfbeeld, haar sogenaamde spieëlbeeldself en haar werklike self. Hoe nader hierdie beelde aanmekaar lê, hoe minder skyn sy probleme met haar besluitneming tydens klere-aankope te hê.

Sproles en Burns (1994:263-299) wys op die belangrikheid van sekere inligtingsbronne tydens verbruikersbesluitneming. Hulle onderskei vyf stadiums in die klereverbruiker se besluitnemingsproses, naamlik bewuswording, belangstelling, evaluasie, die uitprobeerstadium en aanvaarding. Die evaluering en uitprobeer van klere vind hoofsaaklik in die winkel plaas. Tydens hierdie stadiums word klereverbruikers veral deur die massamedia beïnvloed, soos die winkeluitstalling, en persoonlike kommunikasie, soos die advies van die verkoopsdame. Tydens hierdie stadiums kan die verbruiker finaal beïnvloed word om die produk te koop, al dan nie. Sproles en Burns (1994:267) wys daarop dat die klereverbruiker selde, anders as die huishoudelike apparaatverbruiker, vooraf formeel inligting soek oor die kledingstuk wat hy of sy wil aankoop en as't ware vooraf reeds 'n tentatiewe besluit neem nie. Die klereverbruiker soek inligting, weeg kledingstukke teen mekaar op, en neem ' $n$ besluit bìnne die bepaalde winkel en by de punt van aankope.

Eckman et al (1990) noem pertinent die belangrike invloed wat winkelvensteruitstallings en verkoopspersoneel op die verbruiker se besluitnemingsproses kan hê. Daarmee saam stel Sproles en Burns (1994:269) dat die klereverbruiker dikwels op grond van onder meer die winkels se voorkoms, 'n aantal aankooppunte identifiseer en dan uiteindelik 'n keuse maak tussen wat daardie winkels haar bied. Die meeste klereverbruikers besoek twee tot vier winkels wanneer hulle 'n aankoop wil maak en gebruik die inligting wat by die punt van aankope vir hulle beskikbaar is.

Dit is uit die voorafgaande duidelik dat verbruikersbesluitneming op die gebied van kleding nie sommer gelyk gestel kan word aan ander verbruikersbesluitneming nie, aangesien daar faktore is wat die klereverbruiker gedurende die verskillende stadiums beïnvloed. Antwoorde op die volgende vrae behoort dus waardevol te wees:

- Watter verwagtings stel damesklereverbruikers aan die aansig van klerewinkels en aan die voorkoms van die verkoopsdame?

- Gebruik damesklereverbruikers die aansig van damesklerewinkels as 'n simbool van bepaalde kenmerke van die winkel?

- Het die verkoopsdame se voorkoms 'n invloed op die besluitnemingsproses van die damesklereverbruiker?

- Watter rol speel kognitiewe prosesse soos attribusie in die damesklereverbruiker se vorming van eerste indrukke van die winkel se aansig en die verkoopsdame se voorkoms?

Vanuit die simboliese interaksionisme, 'n kognitiewe perspektief en die kleding- en verbruikersteorie dien die konseptuele raamwerk in Figuur 2 as vertrekpunt vir hierdie studie.

Dit is uit die raamwerk duidelik dat die damesklereverbruiker die aankoopsituasie met bepaalde verwagtings (beïnvloed deur ander asook haar selfbeeld, houdings, motiewe en behoeftes) asook bepaalde 


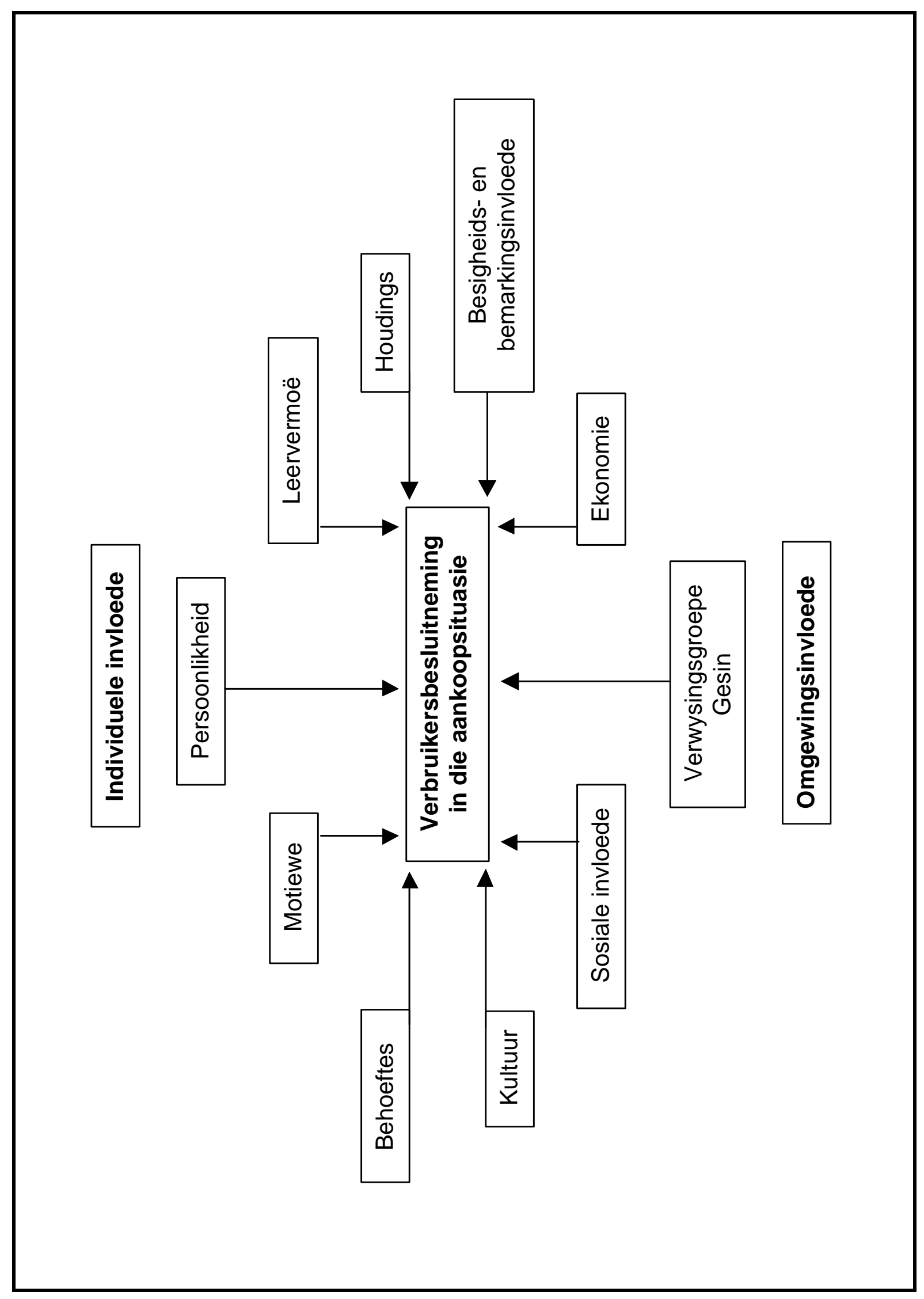

FIGUUR 1: INVLOEDE OP VERBRUIKERSBESLUITNEMING 
kognitiewe en ander individuele vermoëns of geneigdhede betree. Hierdie verwagtings en vermoëns het ' $n$ invloed op haar besluitneming deurdat dit byvoorbeeld haar gebruik en interpretasie van objekte uit die omgewing as simbole beïnvloed asook die mate waarin attribusie as kognitiewe struktuur by haar ' $n$ rol speel. Sy is in die aankoopsituasie interaksie met ander en met die omgewing - in dié geval die verkoopsdame en die winkelaansig - wat op hul beurt as omgewingsinvloede 'n invloed op haar besluitnemingsproses kan hê.

\section{NAVORSINGSONTWERP}

\section{Keuse van respondente}

Met die literatuur en navorsingsvrae in gedagte, asook die oorkoepelende doelwit van die studies, naamlik dat dit as verkennende navorsing onderneem is met die doel om insig en begrip te verkry, is daar vir die keuse van die ondersoekgroep vir elk van die studies besluit op twee Afrikaanssprekende, getroude dames tussen die ouderdomme van 20 en 30 jaar, wat in Pretoria woonagtig is. Die respondente wat in 'n gerieflikheidsteekproef opgeneem is en deeglik bestudeer is, is nie direk by die modewêreld betrokke nie (Velleman, 1995; Malherbe, 1996).

\section{Keuse van data-insamelings- en ander tegnieke}

Met inagneming van die doelwitte van die studie is daar besluit op sekere tegnieke om jong volwasse dames te bestudeer ten einde hulle denke, persepsies en gedrag in detail te kan beskryf. 'n Kwalitatiewe navorsingstyl is gekies met die oog op verkenning en nie op veralgemening na die breë populasie nie.

Ongestruktureerde onderhoude, en die ontleding van stories en sinvoltooiing is as data-insamelingstegnieke gebruik. Bepaalde visuele stimulusmateriaal is gebruik om meer te wete te kon kom van die persepsies van die respondente in ' $n$ bepaalde aankoopsituasie.

Volgens Schurink, in Ferreira at al (1988:139), sluit die voordele van ongestruktureerde onderhoude goed aan by die doelwitte van hierdie navorsing. Die voorwaardes vir die inwin van betroubare inligting, soos gestel in Bogdan en Taylor (1975:104-119), Forcese en Richter (1981:174) en Babbie (1989:224-258) is deurentyd as riglyn gebruik.

Ten einde die dames se verwagtings en persepsies met betrekking tot die winkelaansig te ondersoek, is vyf onderhoude met elk van die dames gevoer (Velleman,1995:57). 'n Bandopnemer is tydens die

\section{Verwagtinge ten opsigte van winkel en verkoopsdame}

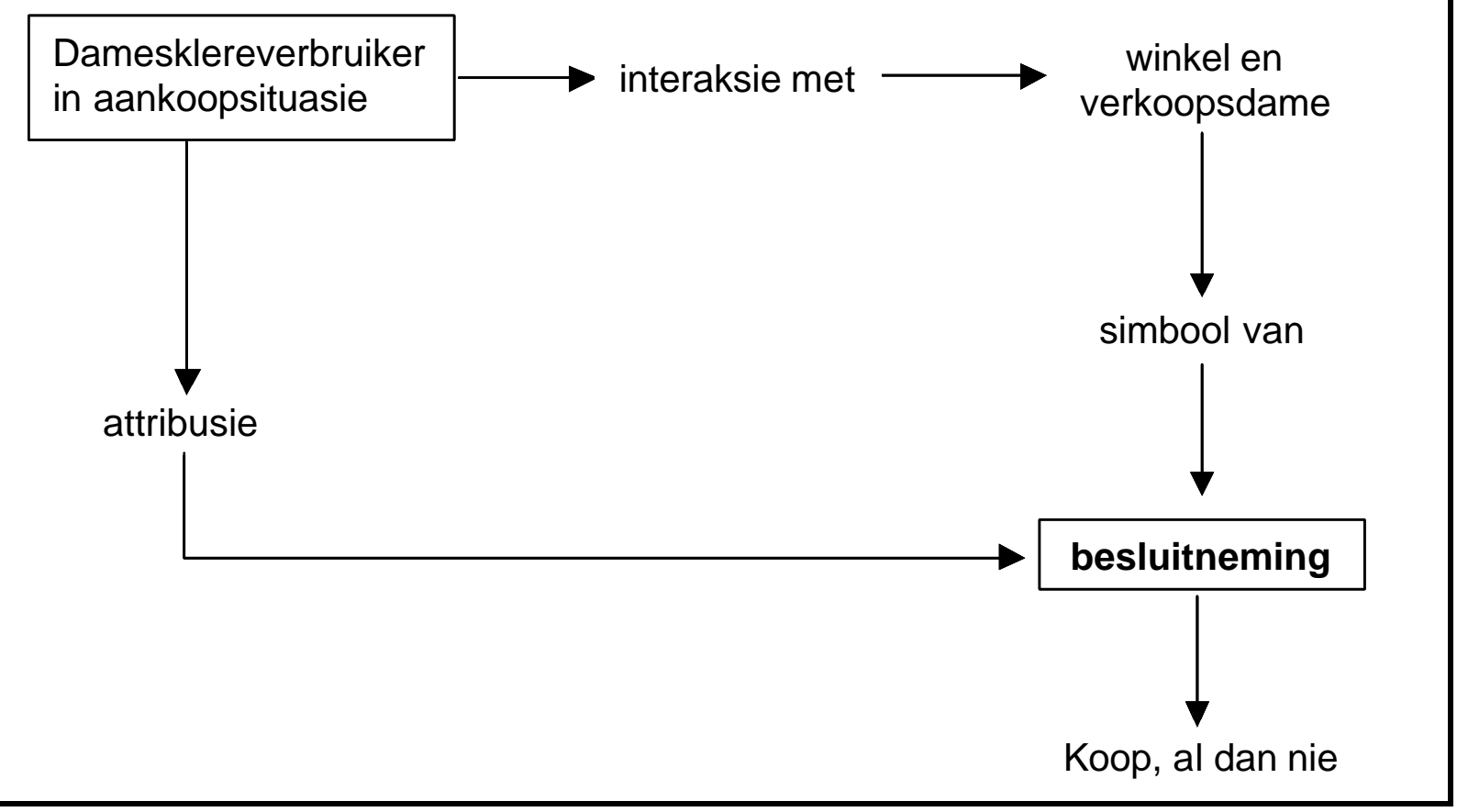

FIGUUR 2: KONSEPTUELE RAAMWERK

'n Kwalitatiewe ondersoek na die invloed van aspekte van die klerewinkel en die verkoopsdame se voorkoms op die damesklereverbruiker se besluitnemingsproses 
onderhoude gebruik om die navorser in staat te stel om inligting so volledig en akkuraat moontlik weer te gee. Daar is ook van verskeie visuele stimuli gebruik gemaak en die respondente is in ' $n$ denkbeeldige koopsituasie geplaas en aangemoedig om te reageer op die aspekte wat vir die navorsing belangrik was. Tydens die eerste onderhoud is die respondente afsonderlik na drie damesklerewinkels geneem wat hulle nog nie voorheen besoek het nie. Dié tegniek is gebruik ten einde die dames in 'n lewensgetroue aankoopsituasie te plaas. Tydens die besoek is foto's van elke winkel se aansig geneem en dié is later weer aan die dames gewys ten einde die gesprek te kon voortsit. Tydens die tweede onderhoud is die foto's asook foto's van die aansigte van ander winkels as stimulus gebruik om die dames in 'n denkbeeldige aakoopsituasie te plaas.

Volgens Bogdan en Taylor (1975:6) is persoonlike dokumente enige materiaal wat ' $n$ persoon in sy of haar eie woorde verskaf en wat lig werp op sy of haar siening ten opsigte van 'n bepaalde lewensaspek. Volgens Schurink (1988:19) is hierdie vorm van datainsameling voordelig omdat dit eerstehandse inligting oor die innerlike belewenisse van individue vaslê. Ten einde meer te wete te kom oor die respondente se ervarings wanneer hulle voor ' $n$ klerewinkel te staan kom, is 'n aantal geskrewe, onvoltooide sinne wat op die doelwitte van die studie betrekking het, tydens die derde onderhoud aan die dames gegee om te voltooi. Ten einde lig te werp op die dames se verwagtings met betrekking tot damesklerewinkels, is daar tydens die vierde onderhoud aan elk die opdrag gegee: "Skryf 'n paragraaf oor die volgende: 'Ek stap graag by 'n klerewinkel in wat/wanneer .... '" Die dames se response is tydens ' $n$ vyfde onderhoud met hulle bespreek.

Drie onderhoude is met elk van die respondente gehou om hulle persepsies met betrekking tot die voorkoms van die verkoopsdames te ondersoek. Alle onderhoude is weer op band opgeneem en die dames is tydens die onderhoude aan stimulustegnieke blootgestel (Malherbe, 1996:42). Die eerste onderhoud het met ' $n$ besoek aan drie klerewinkels gepaard gegaan. Daar is vooraf met die bepaalde verkoopsdames gereël en hul voorkomste is gemanipuleer sodat sommige 'n slordige voorkoms gehad het wat nie by die winkelbeeld gepas het nie, en ander 'n netjiese en paslike voorkoms gehad het.

Good en Kelly (1971), Dillon (1980), Forsythe et al (1984) en Thurstone et al (1990) het almal sukses behaal met die gebruik van foto's of skyfies as visuele stimulusmateriaal in hul navorsing oor voorkomspersepsie. In hierdie studie is tien foto's van drie verkoopsdames, wie se voorkoms weer gemanipuleer is, aan die dames gewys en ' $n$ onderhoud is met elkeen daaroor gehou. Die respondente is ook gevra om 'n gedetailleerde opstel te skryf oor hoe hulle oor verkoopsdames se voorkoms voel en watter invloed hulle meen dit op hulle besluitneming het. Daar is ' $n$ derde onderhoud met elke respondent rondom hierdie opstel gehou.

\section{Verwerking van die data}

Alle gesprekke tydens die onderhoude, is met behulp van ' $n$ bandopnemer vasgelê. Die bandopnames is na die onderhoude ontleed en alle inligting is neergeskryf. Parafrases van die onderhoude en volledige beskrywings van alle ander data wat die respondente verskaf het, is vir ontleding gebruik (Babbie, 1989:278-280).

Volgens Mouton en Marais (1992:104-105) verwys ontleding na die uiteensetting van die samestellende dele van 'n geheel met die oog op kennis. Deur ontleding word faktore wat relevant is vir die verstaan van verskynsels of gebeurtenisse, geïsoleer en kan interpretasie plaasvind. Babbie (1989:300) stel voor dat die volgende prosedures gevolg word om data soos dié te ontleed:

- Kennis van die veld moet opgedoen word en die relevante literatuur moet deurentyd bestudeer word. In hierdie studie was die simboliese interaksionisme, 'n kognitiewe benadering, en die verbruikersgedrag- en kledingteorie van belang.

- Data word gelees en herlees sodat 'n duidelike beeld gevorm kan word oor die tipe inligting wat verkry is. Alle data is deeglik met die gestelde doelwitte in gedagte gelees en herlees.

- Die kategorieë waaronder die data hanteer is, is na aanleiding van die doelwitte van die studies geïdentifiseer:

$\diamond \quad$ Die verwagtings van die damesklereverbruiker ten opsigte van die aansig van die klerewinkels en die voorkoms van die verkoopsdame

$\diamond \quad$ Die damesklereverbruiker se gebruik van die aansig van die damesklerewinkels as simbool van bepaalde kenmerke van die winkel

$\checkmark$ Die invloed van die verkoopsdame se voorkoms op die besluitnemingsproses van die damesklereverbruiker

$\diamond \quad$ Die rol van attribusie in die damesklereverbruiker se vorming van eerste indrukke oor die winkelaansig en die verkoopsdame se voorkoms

$\diamond \quad$ Daar is by die ontleding van die data gelet op aspekte wat herhaaldelik na vore kom ten einde bepaalde konsepte en teoretiese stellings te ontwikkel asook begrip vir waarom dit werklik gaan.

\section{AANBIEDING EN BESPREKING VAN DIE BEVINDINGE}


TABEL 1: $\quad$ VERWAGTINGS VAN DAMESKLEREVERBRUIKERS TEN OPSIGTE VAN DIE AANSIG VAN KLEREWINKELS EN DIE VOORKOMS VAN DIE VERKOOPSDAMES

\begin{tabular}{|c|c|}
\hline Verwagtings & Respondente se stellings \\
\hline $\begin{array}{l}\text { Invloede op verwagtings ten } \\
\text { opsigte van die winkel } \\
\text { Geheelindruk van kwaliteit en } \\
\text { duursaamheid } \\
\text { Eenvoud } \\
\text { Kleur } \\
\text { Andersheid }\end{array}$ & $\begin{array}{l}\text { Ek hou van die hele opset ... } \\
\text { Dit lyk vir my na 'n duur plek hierdie ... as ek moet sê betaal mens vir } \\
\text { kwaliteit en duursaamheid. } \\
\text { Ek sou ook nie kunsblomme daar gesit het nie ... ek sou dit baie meer een- } \\
\text { voudig doen. } \\
\text { Die kleiner venster wat die swart en rooi pakkies het is vir my mooi want dit } \\
\text { is baie meer eenvoudig. } \\
\text { Ek dink nie ek sou by hierdie winkel ingaan nie want die kleure sit my 'n biet- } \\
\text { jie af. } \\
\text { Ek hou nie baie van die winkel se kleure nie. } \\
\text { Dit lyk nie sommer na alledaagse klere nie want alledaagse klere is nie so } \\
\text { deftig en oordoen nie. } \\
\text { Dis iets anders, dit trek jou oog - veral die poppe. }\end{array}$ \\
\hline $\begin{array}{l}\text { Verwagtings wat dames ten } \\
\text { opsigte van die winkel stel } \\
\text { Moet by haar opinie van haarself } \\
\text { pas }\end{array}$ & $\begin{array}{l}\text { As ek moet sê hou ek van hierdie winkel ... die klere is iets wat ek sou kon } \\
\text { aantrek. } \\
\text { Ek hou nie daarvan nie. Ek sou nie hier ingaan nie. Ek dink nie die winkel } \\
\text { pas by my nie. }\end{array}$ \\
\hline $\begin{array}{l}\text { Invloede op verwagtings ten } \\
\text { opsigte van die verkoopsdame } \\
\text { Ouderdom } \\
\text { Voorkoms }\end{array}$ & $\begin{array}{l}\text { Ek hou van 'n verkoopsdame wat al 'n bietjie savvy in die lewe het. } \\
\text { By winkel A het ek van die ouer dame gehou. } \\
\text { Oor die algemeen het die verkoopsdame se voorkoms nie 'n te groot invloed } \\
\text { op my nie, tensy sy baie sleg lyk. } \\
\text { Indien ek dalk twyfel oor 'n kledingstuk en 'n verkoopsdame gee raad sal ek } \\
\text { verseker eers na haar kleredrag kyk. }\end{array}$ \\
\hline $\begin{array}{l}\text { Verwagtings ten opsigte van } \\
\text { die verkoopsdame } \\
\text { Netheid } \\
\text { Vriendelik en spontaan } \\
\text { Moet by winkelbeeld pas } \\
\text { Moet by haar opinie van haarself } \\
\text { pas }\end{array}$ & $\begin{array}{l}\text { Dit sal my dadelik opval as die verkoopsdame slordig aangetrek is. } \\
\text { As die verkoopsdame altyd netjies lyk sal, sy wel 'n invloed op my hê. } \\
\text { Indien haar klere nie } 100 \% \text { is nie, maar sy is baie vriendelik ... sal ek beslis } \\
\text { my aankope by haar wil doen. } \\
\text { Ek kan my eerder vereenselwig met die dames wat by 'n goedkoper winkel } \\
\text { werk omdat daardie klere my beter pas. } \\
\text { As ek in 'n winkel inloop en 'n verkoopsdame het 'n uitrusting aan waarvan } \\
\text { ek hou, sal ek ook die uitrusting wil aanprobeer. } \\
\text { Dit is vir my belangrik hoe 'n verkoopsdame lyk ... hulle moet die tipe klere } \\
\text { aanhê wat ek ook graag wil dra. }\end{array}$ \\
\hline
\end{tabular}

Verwagtings van damesklereverbruikers ten opsigte van die aansig van klerewinkels en die voorkoms van verkoopsdames

Vanuit die simboliese interaksionisme en 'n kognitiewe benadering is dit duidelik dat die verwagtings wat ' $n$ persoon het met betrekking tot ' $n$ bepaalde situasie, mense of dinge, deel van sy of haarself is
(Baron \& Byrne, 1987:95; Kaiser, 1990:41). Hierdie verwagtings het weer ' $n$ invloed op sy of haar gedrag en die wyse waarop hy/sy die situasie interpreteer en beoordeel. Volgens Drake et al (1992:8) sal klereverbruikers slegs by winkels ingaan wat hulle opinie omtrent hulself ondersteun. Die damesklereverbruiker sal dus waarskynlik nie by 'n winkel ingaan wat met die eerste oogopslag nie aan haar verwagtings vol-

'n Kwalitatiewe ondersoek na die invloed van aspekte van die klerewinkel en die verkoopsdame se voorkoms op die damesklereverbruiker se besluitnemingsproses 
doen nie en moontlik ook nie 'n verkoopsdame se raad vra as daardie dame se voorkoms nie inpas by die beeld wat sy van haarself het nie.

Volgens die stellings wat in Tabel 1 vervat is, blyk dit dat veral die geheelindruk van die aansig van die winkel 'n invloed op die dames se verwagtings van die winkel het, en dat kleur, eenvoud en andersheid, asook ' $n$ geheelbeeld van kwaliteit en duursaamheid, 'n belangrike rol speel. Die dames verwag dat die winkelaansig by hul opinie of gevoel omtrent hulself moet pas alvorens hulle die winkel sal binnegaan. Dit sluit aan by die mening van Winters en Goodman $(1984: 159)$ dat vandag se verbruiker meer bewus is van hul eie identiteit en individualiteit, en by die siening van Troxell en Stone (1981:394) wat beklemtoon dat boeiende kwaliteite in die winkelaansig noodsaaklik is om die aandag van verbruikers te trek en dat die uitstalling die beeld van die winkel en voorraad duidelik moet reflekteer.

'n Kognitiewe benadering stel dat mense bepaalde persoons- en rolskemata van ander mense het (Baron \& Byrne,1987:87). Hierdie skemata beïnvloed die verwagtings wat een persoon met betrekking tot 'n ander het, byvoorbeeld dat die persoon op 'n sekere manier moet optree en 'n bepaalde voorkoms moet hê. Volgens Tabel 1 is dit duidelik dat jong damesklereverbruikers bepaalde verwagtings met betrekking tot die voorkoms en optrede van verkoopsdames het en bepaalde kenmerke aan sodanige verkoopsdames toedig op grond van hul voorkoms. Daar word van 'n verkoopsdame verwag om netjies te wees, wat volgens die damesklereverbruiker ' $n$ beeld van bekwaamheid en eerlikheid uitstraal. Daar word ook van die verkoopsdame verwag om vriendelik en spontaan te wees, wat ' $n$ beeld van behulpsaamheid uitstraal. 'n Verkoopsdame moet lyk asof sy bekwaam is en weet waarvan sy praat. Ouderdom speel hier 'n rol aangesien ' $n$ baie jong verkoopsdame nie maklik as bekwaam en met bepaalde ondervinding gesien word nie. Dit is ook vir die damesklereverbruiker belangrik dat die verkoopsdame se voorkoms moet inpas by die beeld van die winkel en die tipe klere wat daar verkoop word, en dat sy haarself met die verkoopsdame se voorkoms moet kan vereenselwig.

Damesklereverbruikers se gebruik van die aansig van klerewinkels as simbool van bepaalde kenmerke van die winkel

Vir die simboliese interaksionis gaan dit primêr om die verstaan en beskryf van mense se interpretasies, belewenisse en gedrag in bepaalde situasies. Die begrip "simbool" het daarom 'n besondere plek in die simboliese interaksionisme en word gesien as dié sosiale objek wat deur die individu geïnterpreteer word ten einde betekenis en verstaanbaarheid aan sy of haar lewe te gee (Charon, 1979:34). Die vraag waarom dit hier gegaan het, was of aspekte van die verbruiker se omgewing, en meer spesifiek die aansig van die damesklerewinkel, deur die damesklereverbruiker as simbool geïnterpreteer word ten einde meer te wete te kom omtrent bepaalde kenmerke van die winkel.

Vanuit die stellings wat in Tabel 2 vervat is, blyk dit dat damesklereverbruikers wel die aansig van damesklerewinkels beskou as 'n simbool van bepaalde kenmerke van die winkel. Dit is opmerklik dat dit veral die geheelindruk van die winkelaansig is wat as simbool uitgelig en geïnterpreteer word. Interessante

\section{TABEL 2: DAMESKLEREVERBRUIKERS SE GEBRUIK VAN DIE AANSIG VAN KLEREWINKELS AS SIMBOOL VAN BEPAALDE KENMERKE VAN DIE WINKEL}

\begin{tabular}{|l|l|}
\hline Aspekte van die aansig as simbool van ... & Respondente se stellings \\
\hline $\begin{array}{l}\text { Geheelindruk as simbool van: } \\
\text { moeite doen }\end{array}$ & $\begin{array}{l}\text {.. ek sou wel ingaan as daar groot koperpilare en persi- } \\
\text { ese matte buite is, want dit sou meer stylvol gelyk het ... } \\
\text { al lyk dit bo my prysklas sou ek nogtans ingaan en gaan } \\
k y k .\end{array}$ \\
kwaliteit en duursaamheid & $\begin{array}{l}\text { Ek hou van die hele opset. Die tipe klere trek my aan. } \\
\text { Ek sou sê die kwaliteit van die klere is goed, want die } \\
\text { hele opset sê vir my so. }\end{array}$ \\
\hline $\begin{array}{l}\text { Interessante/vreemde kenmerke as simbool van: } \\
\text { sosioekonomiese klas }\end{array}$ & $\begin{array}{l}\text { Ek dink dit gaan duur wees, want hier is ' } n \text { klomp goue } \\
\text { goed en juwele wat in die venster rondlê. }\end{array}$ \\
kwaliteit en duursaamheid & $\begin{array}{l}\text { as ' } n \text { mens hier ingaan, dink ek nie jy kan ' } n \text { fout } \\
\text { maak dat jy common of kitsch hier gaan uitstap nie. } \\
\text { Dit lyk classy en eenvoudig, maar die klere lyk op die } \\
\text { oog af of dit goeie kwaliteit is. }\end{array}$ \\
\hline
\end{tabular}


of vreemde kenmerke van die winkelaansig, byvoorbeeld ' $n$ besondere mooi ingang, vreemde winkelpoppe of ' $n$ interessante kleurkombinasie, skep 'n geheelindruk dat daar moeite gedoen is, en dit word dikwels geïnterpreteer as kenmerke van ' $n$ winkel wat klere aan 'n bepaalde sosio-ekonomiese klas lewer. So 'n winkelaansig skep die indruk van duurder en meer eksklusiewe aanbiedinge asook ' $n$ beter kwaliteit en duursamer klere. Die resultate bevestig die sienings van Elkind et al (1964) en Haley en Hendrickson (1974) wat daarop wys dat volwassenes geneig is om ' $n$ geheelbeeld waar te neem en te interpreteer. Dit stem ook ooreen met die sienings van Gellert et al (1971) en van der Westhuizen en Schoeman (1985:304) wat stel dat volwassenes in staat is om wyer waar te neem en meer sensitief is ten opsigte van ' $n$ verskeidenheid sigbare en meer abstrakte simbole in die omgewing.

\section{Die invloed van die verkoopsdame se voorkoms op die besluitnemingsproses van dames- klereverbruikers}

Volgens Baron en Byrne (1987:40-50) speel nie-verbale leidrade (waaronder klere en voorkoms) 'n belangrike rol in kommunikasie tussen mense asook in die persepsies wat individue van ander vorm. Die skrywers stel dit duidelik dat mense geneig is om sulke nie-verbale gedrag te interpreteer as ' $n$ aanduiding van sekere persoonlikheids- en ander kenmerke van ander mense.

Volgens die stellings wat in Tabel 3 vervat is, blyk dit dat die verkoopsdame se voorkoms wel as simbolies van bepaalde kenmerke van die dame geïnterpreteer word en uiteindelik ' $n$ invloed op die besluitnemingsproses van die damesklereverbruiker het. Damesklereverbruikers verkies ' $n$ meer volwasse verkoopsdame met ' $n$ netjiese, stylvolle en deftige voorkoms wat dan geïnterpreteer word as simbolies van bekwaamheid en geloofwaardigheid. Damesklereverbruikers aanvaar graag hulp van 'n verkoopsdame wat aan so ' $n$ beeld voldoen.

Volgens die stellings in Tabel 3 blyk dit ook dat die verkoopsdame se voorkoms nie net geïnterpreteer word as simbolies van haar persoonlike kenmerke nie, maar ook van bepaalde kenmerke van die winkel, waaronder die tipe en kwaliteit klere wat aangebied word. Dit was duidelik dat dit veral die haastige en impulsiewe verbruiker is, die dame wat haar besluit gewoonlik vinnig binne-in die winkel neem, wat makliker deur die verkoopsdame se voorkoms beïnvloed word. Die resultate sluit aan by die mening van Sproles en Burns (1994:207) dat die verkoopsdame veral ' $n$ invloed tydens die evaluasie- en uitprobeerstadiums van die besluitnemingsproses kan hê.

Die rol van attribusie in die damesklereverbruiker se vorming van eerste indrukke van die winkelaansig en die verkoopsdame se voorkoms

Baron en Byrne (1987:47-75) stel dit duidelik dat dit tydens sosiale persepsievorming, en veral wanneer die eerste indrukke gevorm word, vir die individu belangrik is om ' $n$ beeld van die meer permanente eienskappe van ander mense en van situasies te kry. Mense het veral ook ' $\mathrm{n}$ behoefte daaraan om die oor-

TABEL 3:

DIE INVLOED VAN DIE VERKOOPSDAME SE VOORKOMS OP DIE BESLUITNEMINGS PROSES

\begin{tabular}{|l|l|}
\hline Voorkoms as simbool & Respondente se stellings \\
\hline Ouderdom as simbool van bekwaamheid & $\begin{array}{l}\text { Ek hou ook meer van ouer dames. Die een met die den- } \\
\text { imbroek het vir my baie jonk voorgekom. Ek hou van ie- } \\
\text { mand wat al 'n bietjie meer savvy in die lewe het. } \\
\text { Ek sou eerder iets by die ouer dame gekoop het. Sy het } \\
\text { ook vir my mooi en goed versorg gelyk. } \\
\text { Dis vir my 'n elegante vrou dié ... die ander een is net baie } \\
\text { plain ... ek sal nie sommer dink sy het goeie smaak nie. } \\
\text { Ek is beslis 'n impulsiewe koper. As die verkoopsdame } \\
\text { altyd netjies lyk sal sy wel 'n invloed op my besluitneming } \\
\text { hê. } \\
\text { Voorkoms as simbool van die winkelinhoud } \\
\text { lyk nie vir my soos ek graag wil lyk nie. }\end{array}$ \\
$\begin{array}{l}\text { Die verkoopsdame moet vir my aangetrek wees volgens } \\
\text { die tipe klere wat in die winkel te kry is. }\end{array}$ \\
\end{tabular}

'n Kwalitatiewe ondersoek na die invloed van aspekte van die klerewinkel en die verkoopsdame se voorkoms op die damesklereverbruiker se besluitnemingsproses 
TABEL 4: DIE ROL VAN ATTRIBUSIE IN DIE DAMESKLEREVERBRUIKER SE VORMING VAN EERSTE INDRUKKE

\begin{tabular}{|l|l|}
\hline Interpretasie van voorkoms & Respondente se stellings \\
\hline Slordigheid as geen bekwaamheid & $\begin{array}{l}\text { Beslis nie dié een nie, want haar short is te kort en casual ... dit lyk } \\
\text { eerder of sy iemand gaan verlei met haar maag wat so uitsteek. } \\
\text { Nou staan hierdie poppie met haar swart broek en denimbaadjie en } \\
\text { ek dink nie ek vertrou haar opinie nie, want as sy self so lyk wonder } \\
\text { ek hoe sy my verder sal kan help. } \\
\text { Die verkoopsdames was vriendelik en bevoeg; hulle kan die reke- } \\
\text { naar goed werk. }\end{array}$ \\
\hline
\end{tabular}

sake van ander se gedrag te verstaan (in dié geval, die redes vir die verkoopsdame se kleregedrag en die redes vir die winkel se voorkomsgedrag). Die proses waardeur sulke inligting verkry word, staan bekend as attribusie. Die beeld en/of kennis van ander of van 'n situasie wat so verkry word, stel individue in staat om ander mense beter te verstaan, om te weet wat om van die ander mense of van die situasie te verwag, en om hul eie optrede daarvolgens te rig.

Volgens Baron en Byrne (1987:47) word die oorsake van die ander se gedrag tydens attribusie op 'n relatief sistematiese wyse afgelei. Die vraag is watter rol attribusie tydens die vorming van eerste indrukke aan die hand van die winkelaansig en die verkoopsdame se voorkoms speel. Hansen en Deutcher (1977) se navorsing beklemtoon dat attribusie 'n belangrike rol in die verbruiker se keuse van kleinhandelswinkels speel. Daarby voeg Baron en Byrne (1987:50 - 52) en Kaiser (1990:263) dat attribusie 'n belangrike rol tydens die vorming van eerste indrukke aan die hand van ' $n$ persoon se voorkoms kan speel.

Volgens die stellings wat in Tabel 4 vervat is, blyk dit dat attribusie wel 'n rol speel by die eerste indrukke wat damesklereverbruikers aan die hand van die aansig van 'n klerewinkel sowel as die voorkoms van die verkoopsdame vorm. Dit speel veral ' $n$ rol wanneer dit wat die verbruiker waarneem vreemd of anders is en nie inpas by wat sy van 'n winkel of 'n verkoopsdame se voorkoms verwag nie. 'n Slordige voorkoms word byvoorbeeld dadelik waargeneem en geïnterpreteer as ' $n$ teken van ' $n$ verkoopsdame wat "geen savvy" het nie, terwyl 'n besonderse of baie interessante geheelaansig van 'n klerewinkel geïnterpteteer word as 'n teken dat die klere in die winkel besonder duur, eksklusief of van besondere kwaliteit is. Dit bevestig die teorie van attribusie, naamlik dat dit hoofsaaklik vrywillige gedrag is wat vreemd of uniek is, of sosiaal nie besonder aanvaarbaar is nie, wat ' $n$ belangrike rol in attribusie speel. Dit word gewoonlik geïnterpreteer as eie aan die individu self en in dié geval die gevolg van interne faktore van die verkoopsdame of die winkel.

\section{GEVOLGTREKKINGS EN AANBEVELINGS}

In die lig van voorafgaande kan tot die gevolgtrekking gekom word dat verbruikersbesluitneming op die gebied van kleding nie ' $n$ eenvoudige proses is wat noodwendig aan besluitneming op ander gebiede gelyk gestel kan word nie. Dit word in werklikheid beïnvloed en ondersteun deur ' $n$ verskeidenheid interne en eksterne faktore wat as bronne van inligting die klereverbruiker in sy of haar besluit moet ondersteun. Sproles en Burns (1994:263) onderstreep die belangrike feit dat wanneer daar na die klereverbruiker se besluitnemingsproses gekyk word, spesiale aandag gegee moet word aan die punt van aankope waar die besluit meestal gemaak word. Dit is hier waar ' $n$ hele aantal interne en eksterne faktore die verbruiker finaal kan beïnvloed. Dié skrywers beklemtoon dat die klereverbruiker inligting soek, alternatiewe teen mekaar opweeg en die besluit by die punt van aankope neem. Dit vind alles in die klerewinkel plaas. In teenstelling met verbruikers van byvoorbeeld groter huishoudelike en ander apparate, maak die klereverbruiker dikwels by die punt van aankope vinnige en impulsiewe keuses.

Hoewel die klereverbruiker vooraf tuis 'n breë riglyn vir haarself sal saamstel oor die tipe winkel wat sy graag besoek, die hoeveelheid geld wat sy wil spandeer, en die tipe kledingstuk wat sy in gedagte het, vind die finale besluit en inligtingsoeke omtrent haar keuse uiteindelik binne-in die winkel by die punt van aankope plaas. Davis (1984) en Eckman et al (1990) beklemtoon dat hoewel die massamedia in die vorm van byvoorbeeld die televisie en gedrukte media ' $n$ invloed op die klereverbruiker se besluitnemingsproses kan hê, hierdie invloed gewoonlik beperk is tot die bewuswordings- en belangstellingsfases, terwyl 'n baie sterker invloed tydens die uitprobeer-, evaluasieen aanvaardingsfases aan die winkel en die verkoopspersoneel toegeskryf kan word. Die resultate van hierdie studies bevestig bogenoemde sienings.

Damesklereverbruikers se besluitneming word wel deeglik deur die bepaalde winkel en die verkoopspersoneel beïnvloed. Hulle interpreteer reeds die winkel- 
aansig as simbolies van bepaalde kenmerke van die winkel en voorraad wat voorsien word, wat dan onder meer hul besluit om die winkel binne te stap al dan nie beïnvloed. Verder beskou hulle die verkoopsdame se voorkoms as simbolies van bepaalde kenmerke van die dame asook van wat die winkel aanbied. Dit kan weer hul besluit en in watter mate hulle bereid is om advies van die verkoopsdame te aanvaar, beïnvloed.

Sproles en Burns (1994:268) stel verder dat die meeste verbruikers vandag tussen twee tot vier winkels kies waar hulle graag wil koop, en dat veral die haastige en impulsiewe verbruiker haarself dikwels laat beïnvloed deur wat sy by die punt van aankope kry -- moontlik ' $n$ aanvaarbare winkelbeeld en of 'n geloofwaardige verkoopsdame. Hierdie studies bevestig so ' $n$ siening aangesien veral die impulsiewe damesklereverbruiker wat haar besluite vinnig neem en nie eers tuis oor haar aankoop besluit nie, in 'n groter mate deur die verkoopsdame se voorkoms beïnvloed word.

Hierdie resultate is nie net in die kleinhandel vir die kettingklerewinkelgroepe van belang nie, maar veral vir die kleiner klerewinkel of klereboetiek wat weens onder meer finansiële redes nie altyd op die massamedia kan staatmaak om aanbiedinge te adverteer of ' $n$ winkelbeeld te vestig nie. Dit is juis hierdie winkels wat staat behoort te maak op 'n winkelaansig en verkoopspersoneel met 'n voorkoms wat die klereverbruiker positief sal beïnvloed om die winkel te besoek en daar te koop.

Vanuit die simboliese interaksionisme en 'n kognitiewe perspektief is dit duidelik dat die verbruiker ' $n$ aktiewe denkende wese is wat nie 'n aankoopsituasie passief betree nie, maar wat sy of haar verwagtings, waardes, behoeftes, houdings, persoonlike vermoëns en so meer in die situasie inbring (Charon, 1979:65 85). Daarmee saam stel Rousseau (1990:42-59) dit vanuit die verbruikersgedragteorie dat persoonlike veranderlikes in die individu self, soos sy of haar verwagtings en persoonlike vermoëns, 'n groot rol in die besluitnemingsproses tydens aankope speel.

Dit het duidelik uit hierdie studies geblyk dat die jong damesklereverbruiker die aankoopsituasie betree met ' $n$ eie selfbeeld van hoe en wie sy is, waar sy inpas, wat sy van haarself verwag, en watter tipe klere by haar pas. Hierdie beeld beïnvloed weer wat sy verwag ' $n$ winkel haar moet bied om by haar te pas. Dit was duidelik dat die aansig van die klerewinkel en die voorkoms van die verkoopsdame ' $n$ invloed het op die beeld wat sy van die winkel en voorraad vorm, wat uiteindelik by haar eie persoonlike beeld moet pas alvorens sy sal instap en koop.

Dit was ook duidelik dat die damesklereverbruiker wel van kognitiewe strukture soos attribusie gebruik maak tydens die vorming van persepsies -- veral tydens die vorming van eerste indrukke waar sy dan in hierdie geval die winkelaansig en die verkoopsdame se voorkoms gebruik as 'n direkte aanduiding van wat die winkel haar kan bied, hetsy die kwaliteit, duursaamheid, prys, ensovoorts van die klere, hetsy die bekwaamheid van die personeel. Indien die winkelaansig of die voorkoms van 'n verkoopsdame nie aan haar verwagtings voldoen nie, word dit as simbole uitgesonder en geïnterpreteer as die gevolg van interne oorsake in die winkel en/of die verkoopsdame self.

Hierdie resultate bevestig vir kleinhandelaars die belangrikheid en noodsaaklikheid van 'n duidelike en akkurate verbruikersprofiel wat nie net 'n beeld gee van demografiese faktore soos hoe, waar en wanneer ' $n$ bepaalde verbruikersgroep koop nie, maar veral ook ' $n$ beeld van belangrike psigografiese faktore soos die verbruiker se siening van sy of haar eie individualiteit en identiteit, verwagtings, en so meer.

Dit is nie net die klerekleinhandelaar wat voordeel kan trek uit die resultate van hierdie studies nie. Die keuse van perspektiewe en navorsingstegnieke behoort vir navorsers op die gebied van klereverbruik van groot waarde te wees. Drake et al (1992:15-35) en Sproles en Burns (1994:282-298) pleit lank reeds vir klereverbruikersnavorsing wat uit ' $n$ meer mensgerigte perspektief gedoen word. Kaiser (1990:7) pleit sterk vir 'n meer kontekstuele benadering wanneer daar na mense se kledinggedrag gekyk word.

Suid-Afrikaanse verbruikersnavorsing op die gebied van mense se kledinggedrag is skaars. Verder het weinig Suid-Afrikaanse navorsers tot nou toe klereverbruikersnavorsing aan die hand 'n kwalitatiewe navorsingstrategie gedoen. Dit blyk duidelik uit hierdie studies dat die simboliese interaksionisme en ' $n$ kognitiewe perspektief sinvol met ander verbruikersteorieë gekombineer kan word wanneer daar na die verbruiker se gedrag op die gebied van kleding gekyk word. 'n Kwalitatiewe navorsingstrategie behoort ook met groot vrug deur navorsers op die gebied van klereverbruik ingespan te kan word ten einde verbruikers se persepsies en diepste belewenisse op die gebied van kleding bloot te lê.

\section{VERWYSINGS}

BABBIE, E (1989): The practice of social research. 5th ed. Belmont. Woodsworth.

BARON, RA \& BYRNE, D (1987): Social psychology. 6th ed. Boston. Allen \& Bacon.

BOGDAN, RC \& TAYLOR, SJ (1975): Introduction to qualitative research methods: a phenomenological approach to the social sciences. New York. Wiley.

CHARON, JM (1979): Symbolic interaction: an interpretation, an integration. 2nd ed. Englewood Cliffs. Prentice Hall. DAVIS, LL (1984): Clothing and human behavior: a review. Home Econ Res J 12(3):325-339.

DILLON, LS (1980): Business dress for women corporate professionals. Home Econ Res J 9(2):124-129.

DRAKE, FG, SPOON, JH \& GREENWALD, H (1992): Retail fashion promotion and advertising. New York. McMillan. ECKMAN, M, DAMHORST, ML \& KADOLPH, SJ (1990): Toward a model of the in-store purchase decision process: 
consumer use of criteria of evaluating women's apparel. Cloth Text Res J 13:13-22.

ELKIND, D, KOEGLER, RR \& GO, E (1964): Studies in perceptual development: part-whole perception. Child Dev 35:81-90.

FORCESE, DP \& RICHTER, S (1981): Social research methods. Englewood Cliffs. Prentice Hall.

FORSYTHE, SM, DRAKE, MF \& COX Jr, CA (1984): Dress as an influence on the perceptions of management characteristics in women. Home Econ Res J 13(2):112-121.

GELLERT, E, GIRGUS, JS \& COHAN, J (1971): Children's awareness of their bodily appearance: a development study of factors associated with the body percept. Genet Psychol Monogr 84:108-174.

GOOD, EH \& KELLEY, EA (1971): The role clothing plays in the occupational world. J Home Econ 63(5):332-336.

HALEY, EG \& HENDRICKSON, EJ (1974): Children's preferences for clothing and hair styles. Home Econ Res $\mathrm{J} 2$ (3):176-193.

HANSEN, R \& DEUTCHER, T (1977): An empirical investigation of attribute importance in retail store selection. J Retailing 53:59-73.

KAISER, SB (1990): The social psychology of clothing. Symbolic appearances in context. 2nd ed. New York. Macmillan.

MALHERBE, E (1996): Die invloed van die verkoopsdame se voorkoms op die besluitnemingsproses van die verbruiker. Hons-projek. Universiteit van Pretoria.

MILLER, S \& SCHLITT, JK (1985): Interior space: design concepts for personal needs. New York. Praeger.

MOUTON, J \& MARAIS, HC (1990): Metodologie van die geesteswetenskappe - basiese begrippe. 2de uitg. Pretoria. RGN.
O'NEAL, GS \& LAPITSKY, M (1991): Effects of clothing as nonverbal communication on credibility of the message source. Cloth Text Res J 9(3):28-34.

ROUSSEAU, SS (1990): The decision-making process, in du Plessis, PJ, Rousseau, GG \& Blem, NH (eds). Consumer behaviour. A South African perspective. Halfway House. Southern.

SCHURINK, EE (1988): Die metodologie van ongestruktureerde onderhoudvoering, in Ferreira, M, Mouton, J, Puth, G, Schmidt, E \& Schurink, W (red). Inleiding tot kwalitatiewe metodes. Module 3. Pretoria. RGN.

SPROLES, GB (1980): Fashion. Consumer behaviour toward dress. New York. Burgess.

SPROLES, GB \& BURNS, LD (1994): Changing appearances. Understanding dress in contemporary society. New York. Fairchild.

TROXELL, MD \& STONE, E (1981): Fashion merchandising. 3rd ed. New York. Mc Graw Hill.

THURSTONE, JL, LENNON, SJ \& CLAYTON, RV (1990): Influence of age, body type, fashion and garment type on women's professional image. Home Econ Res J 19(2):139150.

VAN DER WESTHUIZEN, TWB \& SCHOEMAN, WJ (1985): Die middelkinderjare, in Louw, DA, Gerdes, LC \& Meyer, WF (red). Menslike ontwikkeling. Pretoria. Haum.

VAN RENSBURG, HCJ \& DE KLERK, GW (1989): Simboliese interaksionisme: 'n mikrososiologiese oriëntasie. S Afr Tydskr Sos 15 (1):46-55

VELLEMAN, AK (1995): Dames se gebruik van die klerewinkelaansig as simbool van bepaalde kenmerke. Hons-projek. Universiteit van Pretoria.

WINTERS, AA \& GOODMAN, S (1984): Fashion advertising and promotion. 6th ed. New York. Fairchild. 